\title{
IMPLEMENTASI PEMBERIAN REMISI NARAPIDANA NARKOTIKA DAN MEKANISME PELAKSANAANYA MENURUT PERARTURAN PEMERINTAH NO $99 / 2012$
}

\section{Risyal Hardiyanto Hidayat ${ }^{1}$, Padmono Wibowo ${ }^{2}$}

Prodi Manajemen Pemasyarakatan,Politeknik Ilmu Pemasyarakatan, email: risyalhardiyanto@gmail.com Prodi Manajemen Pemasyarakatan,Politeknik Ilmu Pemasyarakatan

\begin{abstract}
ABSTRAK
Tindak pidana kejahatan narkotika di Indonesia sangat sering di bicarakan karena dampaknya dapat secara fisik, kesehatan mental, emosi, sikap dalam masyarakat dan dapat merusak generasi muda, selain itu juga jenis pidana narkotika menjadi suatu problematika yang terus meneres di berbagai negara.Republik Indonesia sebagai negara berdasarkan hukum keberadaanya untuk mencapai kehidupan yang lebih baik di masyarakat. Jika seseorang melakukan sesuatu yang merupakan kejahatan, maka seseorang akan dihukum. Namun dalam masa penghukuman tersebut terdapat pengurangan masa pidana atau remisi. Pada lembaga pemasyarakatan remisi diatur pada UU Pemasyarakatan Tahun 1995 Pasal 14 Ayat 1 mengenai hak - hak narapidana pada butir (i). Tujuan dari penelitian ini adalah untuk mengetahui bagaimana pelaksanaan mekanisme pemberian hak remisi terhadap narapidana narkotika.Metode yang digunakan yaitu metode penelitian kualitatif deskriptif dengan jenis penelitian hukum normatif. Teknik pengumpulan data Dengan studi pustaka. Hasil penelitian menunjukkan bahwa pelaksanaan pemberian hak remisi masih terdapat masalah yaitu mengenai pemberian Justice Collaborator sebagai syarat dan ketentuan Perarturan Perundangan No 99 Tahun 2012.
\end{abstract}

\section{ARTICLE INFO}

\section{Kata Kunci:}

Remisi; Justice

Collaborator; Narkotika

\section{Cite this paper:}

Risyal Hardiyanto

Hidayat, P. W., 2020.

Implementasi

Pemberian Remisi

Narapidana Narkotika

Dan Mekanisme

Pelaksanaanya

Menurut Perarturan

Pemerintah No 99 /

2012. Widya Yuridika:

Jurnal Hukum, 3(2).

\section{PENDAHULUAN}

Indonesia adalah Negara yang berdasarkan atas hukum, artinya menjunjung tinggi kaedah-kaedah hukum yang berlaku. Hal tersebut ditegaskan dalam UndangUndang Dasar 1945 Pasal 1 ayat (3) bahwa "Negara Indonesia adalah Negara Hukum". Hukum adalah keseluruhan atau kaedah-kaedah dalam suatu kehidupan bersama, keseluruhan peraturan tentang tingkah laku yang berlaku dalam suatu kehidupan bersama yang pelaksanaanya dapat dipaksakan dengan sanksi. ${ }^{1}$

Pada dasarnya penjatuhan pidana (hukuman) bukan semata mata pemberian derita agar jera, tetapi unsur bimbingan dan pembinaan. Hukuman terhadap pelanggar hukum dilaksanakan di Lembaga Pemasyarakatan (Lapas), dikenal sebagai pembinaan

\footnotetext{
${ }^{1}$ Sudikno Mertokusomo, Mengenal Hukum, Suatu Pengantar, Liberty, Yogjakarta, 2002, hlm. 10-11
} 
dalam lembaga, dengan tujuan agar para pelanggar hukum dapat menyadari kesalahannya dan tidak mengulangi perbuatannya kembali, serta dapat kembali kemasyarakat dan menjalani fungsi sosialnya dengan baik. Seseorang (si pelanggar) yang diputus pidana penjara berkedudukan sebagai narapidana. Dalam hal ini pidana penjara seseorang ditempatkan di Lembaga Pemasyarakatan guna mendapatkan pembinaan.

Pada umumnya narapidana yang ditempatkan dalam Lapas memiliki gejala atau karakteristik yang sama dengan penghuni yang lain, yakni mereka mengalami penderitaan - penderitaan sebagai dampak dari hilangnya kemerdekaan yang dirampas. Di dalam lembaga pemasyarakatan, seorang narapidana mempunyai hak sesuai dengan Pasal 14 ayat (1) huruf i Undang-Undang Nomor 12 Tahun 1995 tentang Pemasyarakatan bahwa salah satu hak narapidana adalah mendapatkan pengurangan masa pidana (remisi) ${ }^{2}$. Remisi yang berarti pengurangan masa pidana yang diberikan kepada narapidana dan anak pidana yang telah berkelakuan baik selama menjalani pidana yang dihitung pada saat menjalani masa pidana dan tidak dihitung dengan mengakumulasi masa penahanan pemotongan atas masa pidana ${ }^{3}$.Dengan pemberian remisi narapidana tidak sepenuhnya menjalani masa hukuman pidananya. Remisi merupakan salah satu sarana hukum yang penting dalam rangka mewujudkan tujuan sistem pemasyarakatan

Pengurangan menjalani pidana (remisi) di Indonesia ini adalah masalah yang perlu diperhatikan, karena pengurangan menjalani masa hukuman tersebut pada satu sisi menyangkut hak manusia yang semestinya dijunjung tinggi agar tercipta keadilan bagi masyarakat. Karena walaupun status dari mereka itu adalah sebagai narapidana yang sedang menjalani hukuman penjara di lembaga pemasyarakatan tetap saja mereka masih merupakan warga negara Indonesia yang mempunyai hak asasi manusia yang harus dilindungi dan dihormati oleh negara.

Peraturan Pemerintah Nomor 99 Tahun 2012 Tentang perubahan kedua Peraturan Pemerintah Nomor 32 Tahun 1999 tentang Syarat dan Tata Cara Pelaksanaan Hak Warga Binaan Pemasyarakatan yang disahkan pada tanggal 12 November 2012, telah memberikan batasan-batasan diberikannya remisi khusus untuk tindak pidana tertentu. Batasanbatasan tersebut dapat dilihat di dalam Pasal 34A ayat (1) Peraturan Pemerintah Nomor 99 Tahun 2012 Tentang Syarat dan Tata Cara Pelaksanaan Hak Warga Binaan Pemasyarakatan: Pemberian Remisi bagi narapidana yang dipidana karena melakukan tindak pidana terorisme, narkotika dan precursor narkotika, psikotropika, korupsi, kejahatan terhadap keamanan negara, kejahatan terhadap hak asasi manusia yang berat, serta kejahatan transnasional terorganisasi lainnya, selain harus memenuhi persyaratan sebagaimana dimaksud dalam pasal 34 juga harus memenuhi persyaratan : a. Bersedia bekerjasama dengan penegak hukum untuk membantu membongkar perkara tindak pidana yang dilakukannya; b. Telah membayar lunas denda uang pengganti sesuai dengan putusan. pengadilan untuk narapidana yang dipidana karena melakukan tindak pidana korupsi; dan c. Telah mengikuti program deradikalisasi yang diselenggarakan oleh LAPAS dan/badan nasional penanggulangan terorisme, serta menyatakan ikrar: 1) Kesetiaan kepada Negara Kesatuan Republik Indonesia secara tetulis bagi Narapidana Warga Negara Indonesia; atau 2) Tidak akan

\footnotetext{
2 UU No 12 Tahun 1995 Tentang Pemasyarakatan

${ }^{3}$ Erdianto Efendi, Hukum Pidana Dalam Dinamika, UR Press, Pekanbaru, 2012, hlm. 134.
} 
mengulangi perbuatan tindak pidana terorisme secara tertulis bagi narapidana Warga negara Asing yang dipidana karena melakukan tindak pidana terorisme.

Namun dalam pelaksanaanya masih ditemukan permasalahan dalam pemberian remisi berdasarkan Peraturan Pemerintah Nomor 99 Tahun 2012 Tentang Syarat dan Tata Cara Pelaksanaan Hak Warga Binaan Pemasyarakatan yaitu mengenai justice collaborator (bersedia bekerjasama dengan penegak hukum untuk membantu membongkar perkara tindak pidana yang dilakukannya) yang perlu diperbaiki lantaran harus dikembalikan kepada penegak hukum yang menangani perkara narapidana. Dalam konsepnya pemberian justice collaborator disertakan pada saat putusan atau inkrah dari hakim sehingga pemasyrakatan hanya menjalankan tugas pembinaanya saja. Karena hal tersebut dapat dimanfaatkan oleh sebagian oknum dengan jual beli justice collaborator di lembaga penegak hukum. Dan juga seakan-akan lembaga pemasyarakatan yang dititikberatkan dalam pemberian JC. Seharusnya pihak penahan atau pengadilan sudah menebitkan JC pada saat narapidana tersebut ditempatkan dilapas sehingga kesannya lembaga pemasyaraktan yang mengemis untuk diberikan justice collaborator.

Dari penjelasan yang sudah diuraikan di atas, maka penulis tertarik untuk mengambil judul "Implementasi Pemberian Remisi Narapidana Narkotika dan Mekanisme Pelaksanaanya Menurut Perarturan Pemerintah No 99 Tahun 2012".

Adapaun tujuan dari penelitian ini untuk menjelaskan dan menggambarkan pengaturan pemberian hak remisi tindak pidana narkotika berdasarkan sistem hukum dan mekanisme pemberian Hak Remisi narapidana narkotika terhadap PP No 99 Tahun 2012

Sedangkan pada penilitian ini menggunakan metode kualitatif bersifat deskriptif dengan pengambilan data menggunakan studi pustaka (library research), dengan jenis penelitian hukum yuridis normatif, yaitu suatu penelitian yang mengkaji mengenai asasasas hukum, sistematika hukum, taraf sinkronisasi hukum dengan membandingkan pada praktek dilapangan dalam penerapan UU No 99 Tahun 2012. Penelitian terhadap asas-asas hukum dilakukan terhadap kaidah-kaidah hukum yang merupakan patokanpatokan berprilaku atau bersikap tidak pantas. Penelitian tersebut dapat dilakukan (terutama) terhadap bahan hukum primer dan sekunder. ${ }^{4}$

Sumber data yang digunakan Sumber data yang digunakan oleh penulis dalam penelitian ini adalah sumber data sekunder. Adapun data sekunder di dalam penelitian ini dapat dibedakan menjadi 2, yakni:

a. Bahan Hukum Primer, yaitu bahan hukum yang mengikat yang dapat terdiri dari:

1) Undang-Undang Dasar Republik Indonesia Tahun 1945.

2) Undang-Undang Nomor 12 Tahun 1995 tentang Pemasyarakatan.

3) Undang-Undang Nomor 39 Tahun 1999 tentang Hak Asasi Manusia.

4) Keputusan Presiden Republik Indonesia 7 Nomor 174 Tahun 1999 tentang Remisi.

5) Peraturan Pemerintah Nomor 99 Tahun 2012 Tentang Perubahan Kedua Atas Peraturan Pemerintah Nomor 32 Tahun 1999 tentang Syarat dan Tata Cara Pelaksanaan Hak Warga Binaan Pemasyarakatan.

b.Bahan Hukum Sekunder, yaitu bahan hukum yang memberikan penjelasan mengenai bahan hukum primer, misalnya:

1) Buku-buku literatur yang berhubungan dengan permasalahan remisi.

2) Makalah-makalah/jurnal/karya tulis yang berkaitan dengan pemberian remisi.

\footnotetext{
${ }^{4}$ Soerjono Soekanto dan Sri Mamudji, Penelitian Hukum Normatif : Suatu Tinjauan Singkat, PT Rajagrafindo Persada, Jakarta, 2006, hlm. 62.
} 
3) Hasil penelitian para pakar hukum/lembaga yang bergerak dalam penelitian tersebut.

\section{HASIL DAN PEMBAHASAN}

\section{A. Pengaturan Hak Remisi Narapidana}

Kementrian Hukum dan Ham sebagai payung sistem pemasyarakatan Indonesia, menyelenggarakan sistem pemasyarakatan agar narapidana dapat memperbaiki diri dan tidak mengulangi tindak pidana, sehingga narapidana dapat diterima kembali dalam lingkungan masyarakatnya, kembali aktif berperan dalam pembangunan serta hidup secara wajar sebagai seorang warga negara. Peran serta pembinaan narapidana tidak lepas dari Lapas. Pelaksanaan remisi di Indonesia berdasarkan: 1. Keppres No. 120 Tahun 1995 tentang Ampunan Istimewa; 2. Keppres No. 174 Tahun 1999 tentang Remisi; 3. Keputusan Menteri Hukum dan PerundangUndangan No. M.09.HN.02.01 Tahun 1999 tentang Pelaksanaan Keppres No. 174 Tahun 1999; 4.

Keputusan Menteri Hukum dan Perundang-Undangan No. M.10.HN.02.01 Tahun 1999 tentang Pelimpahan Wewenang Pemberian Remisi Khusus; 5. Keputusan Menteri Kehakiman No. 04.HN.02.01 Tahun 1988 tentang Tambahan Remisi bagi Narapidana yang menjadi Donor Organ Tubuh dan Donor Darah; dan 6. Peraturan Pemerintah Nomor 32 Tahun 1999 tentang Syarat dan Tata Cara Pelaksanaan Hak Warga Binaan Pemasyarakatan ("PP 32/1999") serta yang terbaru yaitu Perarturan Pemerintah Nomor 99 Tahun 2012.

Berdasarkan ketentuan Pasal 2 dan Pasal 3 Keppres No. 174 Tahun 1999 tentang Remisi, ada beberapa jenis Remisi, yaitu: Pertama, Remisi Umum, adalah remisi yang diberikan pada hari peringatan Proklamasi Kemerdekaan Republik Indonesia tanggal 17 Agustus. Kedua, Remisi Khusus, adalah remisi yang diberikan pada hari besar keagamaan yang dianut oleh narapidana dan anak pidana yang bersangkutan dengan ketentuan jika suatu agama mempunyai lebih dari satu hari besar keagamaan dalam setahun, maka yang dipilih adalah hari besar yang paling dimuliakan oleh penganut agama yang bersangkutan. Berdasarkan Keputusan Menteri Hukum dan Perundangundangan No. M.09. HN.02.01 Tahun 1999 tentang Pelaksanaan Keppres No. 174 Tahun 1999, Pasal 3 ayat (2) menegaskan bahwa pemberian remisi khusus dilaksanakan pada: setiap hari raya Idul Fitri bagi narapidana dan anak pidana yang beragama Islam, setiap hari Natal bagi narapidana dan anak pidana yang beragama Kristen, dan setiap hari raya Nyepi bagi narapidana dan anak pidana yang beragama Hindu, serta setiap hari raya Waisak bagi narapidana dan anak pidana yang beragama Budha. Ketiga, Remisi Tambahan diberikan apabila narapidana atau anak pidana yang selama menjalani pidana telah: berbuat jasa kepada negara; dan melakukan perbuatan yang bermanfaat bagi negara atau kemanusiaan; serta melakukan perbuatan yang membantu kegiatan pembinaan di Lapas.

Dengan banyaknya macam-macam remisi, hal ini merupakan kelonggaran yang cukup banyak oleh pemerintah kepada narapidana untuk selalu memperbaiki sikap tingkah laku dan perbuatannya khususnya di dalam Lapas, sehingga akan memperoleh kemudahan untuk diberikannya remisi. berbagai kesempatan diperoleh narapidana yang berkeinginan sungguh-sungguh akan berbuat baik di dalam kehidupan masyarakat nanti. Namun apabila keinginan untuk mendapatkan remisi hanya sekedar untuk bisa semakin cepat keluar dari Lapas tanpa hasrat untuk memperbaiki perbuatannya di 
masyarakat nanti maka, tentu ini bukan merupakan cita-cita dari sistem pemasyarakatan yang diterapkan di dalam pembinaan narapidana, sehingga kesempatan yang diberikan itu menjadi sia-sia saja. Remisi diberikan oleh Menkumham berdasarkan Pasal 1 ayat (2) Keppres No. 174 Tahun 1999 menegaskan bahwa Menteri dapat mendelegasikannya kepada Kantor Wilayah. Penetapan pemberian remisi tersebut dilaksanakan dengan keputusan Kepala Kantor Wilayah atas nama Menteri; sedangkan pada Pasal 2 ayat (2) menegaskan bahwa, segera setelah mengeluarkan penetapan tentang remisi, Kepala Kantor Wilayah wajib menyampaikan laporan tentang penetapan pengurangan masa pidana kepada Menteri melalui Direktur Jenderal Pemasyarakatan. Pemberian remisi khusus hari raya keagamaan dapat dilimpahkan kepada Lapas, Kepala Rumah Tahana Negara, dan Kepala Cabang Rumah Tahanan Negara.

\section{B. Sistem Hukum Pengaturan Tindak Pidana Narkotika}

Ruang lingkup hukum pidana mencakup tiga ketentuan yaitu tindak pidana, pertanggungjawaban, dan pemidanaan. Ketentuan pidana yang terdapat dalam UU No. 35 Tahun 2009 tentang Narkotika dirumuskan dalam Bab XV Ketentuan Pidana Pasal 111 sampai dengan Pasal 148. Undang-Undang No. 35 Tahun 2009 tentang Narkotika, terdapat empat kategorisasi tindakan melawan hukum yang dilarang oleh undangundang dan dapat diancam dengan sanksi pidana ${ }^{5}$, yakni:

1. Kategori pertama, yakni perbuatan-perbuatan berupa memiliki, menyimpan, menguasai atau menyediakan narkotika dan prekursor narkotika (Pasal 111 dan 112 untuk narkotika golongan I, Pasal 117 untuk narkotika golongan II dan Pasal 122 untuk narkotika golongan III serta Pasal 129 huruf (a));

2. Kategori kedua, yakni perbuatan-perbuatan berupa memproduksi, mengimpor, mengekspor, atau menyalurkan narkotika dan precursor narkotika (Pasal 113 untuk narkotika golongan I, Pasal 118 untuk narkotika golongan II, dan Pasal 123 untuk narkotika golongan III serta Pasal 129 huruf(b));

3. Kategori ketiga, yakni perbuatan-perbuatan berupa menawarkan untuk dijual, menjual, membeli, menerima, menjadi perantara dalam jual beli, menukar, atau menyerahkan narkotika dan prekursor narkotika (Pasal 114 dan Pasal 116 untuk narkotika golongan I, Pasal 119 dan Pasal 121 untuk narkotika golongan II Pasal 124 dan Pasal 126 untuk narkotika golongan III serta Pasal 129 huruf(c));

4. Kategori keempat, yakni perbuatan-perbuatan berupa membawa, mengirim, mengangkut atau mentransit narkotika dan prekursor narkotika (Pasal 115 untuk narkotika golongan I, Pasal 120 untuk narkotika golongan II dan Pasal 125 untuk narkotika golongan III serta Pasal 129 huruf (d)).

Undang-Undang No. 35 Tahun 2009 tentang Narkotika telah mengatur jenis-jenis sanksi yang diberikan pada tindak pidana narkotika antara lain:

1. Tindak Pidana bagi penyalah guna atau sebagai korban penyalahgunaan narkotika, penyalah guna tersebut wajib menjalani rehabilitasi medis dan rehabilitasi sosial.

\footnotetext{
${ }^{5}$ Siswanto Sunarso, Politik Hukum Dalam Undang-Undang Narkotika, Jakarta:Rineka Cipta, 2012, hlm. 256
} 
2. Tindak Pidana Orang Tua / Wali dari Pecandu Narkotika Narkotika yang Belum Cukup Umur (Pasal 128) dipidana dengan pidana kurungan paling lama 6 (enam) bulan atau pidana denda paling banyak Rp1.000.000,00 (satu juta rupiah).

3. Tindak Pidana yang Dilakukan oleh Korporasi (Pasal 130) Dipidana dengan pidana penjara dan pidana denda dengan pemberatan 3 (tiga) kali. Korporasi dapat dijatuhi korporasi dapat dijatuhi pidana tambahan berupa: a. pencabutan izin usaha dan/atau b. pencabutan status badan hukum.

4. Tindak pidana bagi Orang yang Tidak Melaporkan Adanya Tindak Pidana Narkotika (Pasal 131). Dipidana dengan pidana penjara paling lama 1 (satu) tahun atau pidana denda paling banyak Rp50.000.000,00 (lima puluh juta rupiah).

5. Tindak Pidana terhadap Percobaan dan Permufakatan Jahat Melakukan Tindak Pidana Narkotika dan Prekursor (Pasal 132) Ayat (1), dipidana dengan pidana pidana penjara yang sama sesuai dengan ketentuan sebagaimana dimaksud dalam Pasal-Pasal tersebut. Ayat (2), dipidana pidana penjara dan pidana denda.maksimumnya ditambah $1 / 3$ (sepertiga).

6. Tindak Pidana bagi Menyuruh, Memberi, Membujuk, Memaksa dengan Kekerasan, Tipu Muslihat, Membujuk Anak (Pasal 133) ayat (1), dipidana dengan pidana mati atau pidana penjara seumur hidup, atau pidana penjara paling singkat 5 (lima) tahun dan paling lama 20 (dua puluh) tahun dan pidana denda paling sedikit Rp2.000.000.000,00 (dua miliar rupiah) dan paling banyak Rp20.000.000.000,00 (dua puluh miliar rupiah). ayat (2), dipidana dengan pidana penjara paling singkat 5 (lima) tahun dan paling lama 15 (lima belas) tahun dan pidana denda paling sedikit Rp1.000.000.000,00 (satu miliar rupiah) dan paling banyak Rp10.000.000.000,00 (sepuluh miliar rupiah).

7. Tindak Pidana bagi Pecandu Narkotika yang Tidak Melaporkan Diri (Pasal 134) ayat (1), dipidana dengan pidana kurungan paling lama 6 (enam) bulan atau pidana denda paling banyak Rp2.000.000,00 (dua juta rupiah). ayat (2), dipidana dengan pidana kurungan paling lama 3 (tiga) bulan atau pidana denda paling banyak Rp1.000.000,00 (satu juta rupiah).

8. Tindak Pidana bagi Pengurus Industri Farmasi yang Tidak Melaksanakan Kewajiban (Pasal 135). Dipidana dengan pidana penjara paling singkat 1 (satu) tahun dan paling lama 7 (tujuh) tahun dan pidana denda paling sedikit Rp40.000.000,00 (empat puluh juta rupiah) dan paling banyak Rp400.000.000,00 (empat ratus juta rupiah).

9. Tindak Pidana terhadap Hasil-Hasil Tindak Pidana Narkotika dan/atau Prekursor Narkotika (Pasal 137) huruf (a), dipidana dengan pidana penjara paling singkat 5 (lima) tahun dan paling lama 15 (lima belas) tahun dan pidana denda paling sedikit Rp1.000.000.000,00 (satu miliar rupiah) dan paling banyak Rp10.000.000.000,00 (sepuluh miliar rupiah). Huruf (b), dipidana dengan pidana penjara paling singkat 3 (tiga) tahun dan paling lama 10 (sepuluh) tahun dan pidana denda paling sedikit Rp500.000.000,00 (lima ratus juta rupiah) dan paling banyak Rp5.000.000.000,00 (lima miliar rupiah). 
10.Tindak Pidana terhadap Orang yang Menghalangi atau Mempersulit Penyidikan, Penuntutan dan Pemeriksaan Perkara (Pasal 138) Dipidana dengan pidana penjara paling lama 7 (tujuh) tahun dan pidana denda paling banyak Rp500.000.000,00 (lima ratus juta rupiah).

11.Tindak Pidana bagi Nahkoda atau Kapten Penerbang yang Tidak Melaksanakan Ketentuan Pasal 27 dan Pasal 28 (Pasal 139) dipidana dengan pidana penjara paling singkat 1 (satu) tahun dan paling lama 10 (sepuluh) tahun dan pidana denda paling sedikit Rp100.000.000,00 (seratus juta rupiah) dan paling banyak Rp1.000.000.000,00 (satu miliar rupiah).

12.Tindak Pidana bagi PPNS, Penyidik Polri, Penyidik BNN yang Tidak Melaksanakan Ketentuan tentang Barang Bukti (Pasal 140) dipidana dengan pidana penjara paling singkat 1 (satu) tahun dan paling lama 10 (sepuluh) tahun dan pidana denda paling sedikit Rp100.000.000,00 (seratus juta rupiah) dan paling banyak Rp1.000.000.000,00 (satu miliar rupiah).

13.Tindak Pidana bagi Kepala Kejaksaan Negeri yang Tidak Melaksanakan Ketentuan Pasal 91 Ayat(1) (Pasal 141) dipidana dengan pidana penjara paling singkat 1 (satu) tahun dan paling lama 10 (sepuluh) tahun dan pidana denda paling sedikit Rp100.000.000,00 (seratus juta rupiah) dan paling banyak Rp1.000.000.000,00 (satu miliar rupiah).

14.Tindak Pidana bagi Petugas Laboratorium yang Memalsukan Hasil Pengujian (Pasal 142) dipidana dengan pidana penjara paling lama 7 (tujuh) tahun dan pidana denda paling banyak Rp500.000.000,00 (lima ratus juta rupiah).

15.Tindak Pidana bagi Saksi yang Memberikan Keterangan Tidak Benar (Pasal 143) dipidana dengan pidana penjara paling singkat 1 (satu) tahun dan paling lama 10 (sepuluh) tahun dan pidana denda paling sedikit Rp 60.000.000,00 (enam puluh juta rupiah) dan paling banyak Rp 600.000.000,00 (enam ratus juta rupiah).

16.Tindak Pidana bagi Setiap Orang yang Melakukan Pengulangan Tindak Pidana (Pasal 144) dipidana dengan pidana maksimumnya ditambah dengan $1 / 3$ (sepertiga).

17.Tindak Pidana yang dilakukan Pimpinan Rumah Sakit, Pimpinan Lembaga Ilmu Pengetahuan, Pimpinan Industri Farmasi, dan Pimpinan Pedagang Farmasi (Pasal 147) dipidana dengan pidana penjara paling singkat 1 (satu) tahun dan paling lama 10 (sepuluh) tahun dan pidana denda paling sedikit Rp100.000.000,00 (seratus juta rupiah) dan paling banyak Rp1.000.000.000,00 (satu miliar rupiah).

Pasal 136 UU No. 35 Tahun 2009 memberikan sanksi berupa narkotika dan prekursor narkotika serta hasil-hasil yang diperoleh dari tindak pidana narkotika baik itu aset bergerak atau tidak bergerak maupun berwujud atau tidak berwujud serta barang-barang atau peralatan yang digunakan untuk tindak pidana narkotika dirampas untuk negara. Pasal 146 juga memberikan sanksi terhadap warga negara asing yang telah melakukan tindak pidana narkotika ataupun menjalani pidana narkotika yakni dilakukan pengusiran wilayah negara Republik Indonesia dan dilarang masuk kembali ke wilayah negara Republik Indonesia. Sedangkan pada Pasal 148 bila putusan denda yang diatur dalam undangundang ini tidak dibayarkan oleh pelaku tindak pidana 
narkotika maka pelaku dijatuhi penjara paling lama dua tahun sebagai pengganti pidana denda yang tidak dapat dibayar.

\section{Telaah Hak Remisi bagi Narapidana Narkotika}

Sebelum membahas remisi bagi narapidana narkotika, bahwa remisi adalah hak narapidana. Hal itu diatur pada Pasal 14 ayat (1) Undang-Undang Nomor 12 Tahun 1995 tentang Pemasyarakatan("UU 12/1995") yaitu:

Narapidana (terpidana yang menjalani pidana hilang kemerdekaan di lembaga permasyarakatan $)^{6}$ berhak:

a. melakukan ibadah sesuai dengan agama atau kepercayaannya;

b. mendapat perawatan, baik perawatan rohani maupun jasmani;

c. mendapatkan pendidikan dan pengajaran;

d. mendapatkan pelayanan kesehatan dan makanan yang layak;

e. menyampaikan keluhan;

f. mendapatkan bahan bacaan dan mengikuti siaran media massa lainnya yang tidak dilarang;

g. mendapatkan upah atau premi atas pekerjaan yang dilakukan;

h. menerima kunjungan keluarga, penasihat hukum, atau orang tertentu lainnya;

i. mendapatkan pengurangan masa pidana (remisi);

j. mendapatkan kesempatan berasimilasi termasuk cuti mengunjungi keluarga;

k. mendapatkan pembebasan bersyarat;

l. mendapatkan cuti menjelang bebas; dan

m. mendapatkan hak-hak lain sesuai dengan peraturan perundang-undangan yang berlaku.

Remisi adalah pengurangan masa menjalani pidana yang diberikan kepada narapidana dan Anak Pidana yang memenuhi syarat-syarat yang ditentukan dalam peraturan perundang-undangan. ${ }^{7}$ Secara spesifik hak remisi disebutkan dalam Pasal 34 ayat (1) PP 99/2012 yakni yang berhak mendapatkan remisi adalah narapidana dan anak pidana.

Syarat Pemberian Remisi, Untuk diberikan remisi, seorang narapidana harus memenuhi syarat-syarat berikut ${ }^{8}$ :

a. Narapidana berkelakukan baik

b. Persyaratan berkelakuan baik ini dibuktikan dengan:

c. tidak sedang menjalani hukuman disiplin dalam kurun waktu 6 (enam) bulan terakhir, terhitung sebelum tanggal pemberian Remisi; dan

d. telah mengikuti program pembinaan yang diselenggarakan oleh Lembaga Pemasyarakatan ("Lapas") dengan predikat baik.

e. Telah menjalani masa pidana lebih dari 6 (enam) bulan.

Remisi ini diberikan oleh Menteri Hukum dan Hak Asasi Manusia ("Menteri") yang ditetapkan dengan keputusan Menteri. Untuk narapidana yang dipidana karena melakukan tindak pidana terorisme, narkotika dan prekursor

\footnotetext{
${ }^{6}$ Pasal 1 angka 7 UU 12/1995

7 Pasal 1 angka PP 32/1999 dan Pasal 1 angka 3 Peraturan Menteri Hukum dan Hak Asasi Manusia Nomor 3

Tahun 2018 tentang Syarat dan Tata Cara Pemberian Remisi, Asimilasi, Cuti Mengunjungi Keluarga,

Pembebasan Bersyarat, Cuti Menjelang Bebas, dan Cuti Bersyarat ("Permenkumham 3/2018”)

${ }^{8}$ Pasal 34 ayat (2) dan (3) PP 99/2012 dan Pasal 5 Permenkumham 3/2018
} 
narkotika, psikotropika, korupsi, kejahatan terhadap keamanan negara, kejahatan hak asasi manusia yang berat, serta kejahatan transnasional terorganisasi lainnya, selain syarat di atas, ada syarat tambahan, yaitu ${ }^{9}$ :

a. bersedia bekerja sama dengan penegak hukum untuk membantu membongkar perkara tindak pidana yang dilakukannya;

b. telah membayar lunas denda dan uang pengganti sesuai dengan putusan pengadilan untuk Narapidana yang dipidana karena melakukan tindak pidana korupsi; dan

c. telah mengikuti program deradikalisasi yang diselenggarakan oleh Lapas dan/atau Badan Nasional Penanggulangan Terorisme, serta menyatakan ikrar:

1. kesetiaan kepada Negara Kesatuan Republik Indonesia secara tertulis bagi Narapidana Warga Negara Indonesia, atau

2. tidak akan mengulangi perbuatan tindak pidana terorisme secara tertulis bagi Narapidana Warga Negara Asing, yang dipidana karena melakukan tindak pidana terorisme.

Yang memberikan remisi untuk narapidana yang dipidana karena melakukan tindak pidana terorisme, narkotika dan prekursor narkotika, psikotropika, korupsi, kejahatan terhadap keamanan negara, kejahatan hak asasi manusia yang berat, serta kejahatan transnasional terorganisasi lainnya ini adalah Menteri setelah mendapat pertimbangan tertulis dari menteri dan/atau pimpinan lembaga terkait dan ditetapkan dengan keputusan menteri ${ }^{10}$.

\section{Mekanisme Pelaksanaan Hak Remisi Narapidana Narkotika}

Kementrian Hukum dan HAM mengkaji revisi Pemerintah (PP) Nomor 99 Tahun 2012 tentang Syarat dan Tata Cara Pelaksanaan Hak Warga Binaan Pemasyarakatan. Hal ini dilakukan Kemenkumham dengan mengumpulkan para pakar hukum Indonesia mengenai Pembuatan Cetak Biru Pembangunan Hukum Indonesia di Bidang hukum dan Rancangan Peraturan Pemerintah Tentang Hak Warga Binaan Pemasyarakatan.

Pada pelaksanaan PP Nomor 99 Tahun 2012 banyak mengalami kendala dan permasalahan dalam praktiknya tentang mengenai pemeberian remisi, pb, cb pada penyertaan Justice collaborator bagi narapidana koruptor, teroris dan narkoba atau jenis tindak pidana High Risk. Secara spesifik hak remisi disebutkan dalam Pasal 34 ayat (1) PP 99/2012 yakni yang berhak mendapatkan remisi adalah Narapidana berkelakukan baik. Persyaratan berkelakuan baik ini dibuktikan dengan ${ }^{11}$ :

1. tidak sedang menjalani hukuman disiplin dalam kurun waktu 6 (enam) bulan terakhir, terhitung sebelum tanggal pemberian Remisi; dan

2. telah mengikuti program pembinaan yang diselenggarakan oleh Lembaga Pemasyarakatan ("Lapas") dengan predikat baik.

3. Telah menjalani masa pidana lebih dari 6 (enam) bulan narapidana dan anak pidana

Sedangkan khusus untuk pemberian remisi bagi narapidana yang dipidana karena melakukan tindak pidana terorisme, narkotika dan prekursor narkotika, psikotropika, korupsi, kejahatan terhadap keamanan negara, kejahatan hak asasi manusia yang berat, serta kejahatan transnasional terorganisasi lainnya, selain syarat di atas, ada syarat tambahan, yaitu :

\footnotetext{
${ }^{9}$ Pasal 34A ayat (1) PP 99/2012 dan Pasal 8 - Pasal 11 Permenkumham 3/2018

10 Pasal 34B ayat (2) dan ayat (4) PP 99/2012

${ }^{11}$ Pasal 34A ayat (1) PP 99/2012 dan Pasal 8 - Pasal 11 Permenkumham 3/2018
} 
1. bersedia bekerja sama dengan penegak hukum untuk membantu membongkar perkara tindak pidana yang dilakukannya;

2. telah membayar lunas denda dan uang pengganti sesuai dengan putusan pengadilan untuk Narapidana yang dipidana karena melakukan tindak pidana korupsi; dan telah mengikuti program deradikalisasi yang diselenggarakan oleh Lapas dan/atau Badan Nasional Penanggulangan Terorisme, serta menyatakan ikrar:

- kesetiaan kepada Negara Kesatuan Republik Indonesia secara tertulis bagi Narapidana Warga Negara Indonesia, atau

- tidak akan mengulangi perbuatan tindak pidana terorisme secara tertulis bagi Narapidana Warga Negara Asing.

Pemberian remisi pada narapidana yang dipidana karena melakukan tindak pidana narkotika dan prekursor narkotika, psikotropika yang disebutkan di atas hanya berlaku terhadap narapidana yang dipidana dengan pidana penjara paling singkat 5 (lima) tahun. Artinya tindak pidana tersebut jika diberikan Remisi hanya masa pidananya 5 dan diatas lima tahun dan jika masa pidananya dibawah 5 tahun tidak menggunakan perarturan ini.

Hal ini PP N0 99 Tahun 2012 tentang Syarat dan Tata Cara Pelaksanaan Hak Warga Binaan Pemasyarakatan, mengatur pengetatan pemberian remisi dan pembebasan bersyarat kepada napi korupsi, narkoba, dan terorisme, dengan persyaratan pada PP N0 99 Tahun 2012 yang dianggap lebih ribet dengan kenyataanya yang tidak sesuai dilapangan. Selain itu seharusnya lebih baik mengatur pada kasus narkoba karena kasus narkoba sebagian besar merupakan kejahatan dilapas. hal ini disebabkan lantaran konsep penghukumannya tidak jelas antara pengedar dan pemakai.

Justice Collaborator adalah saksi pelaku yang bekerjasama dengan penyidik atau jaksa penuntut umum dalam mengungkap kasus tertentu, seseorang dapat dinyatakan sebagai Justice Collaborator apabila mengakui kejahatannya, bukan pelaku utama, bersedia membantu membongkar kasus, serta bersedia mengembalikan asetaset hasil dari korupsi yang dilakukannya. Dan dalam prosesnya menyatakan bahwa yang bersangkutan telah memberikan keterangan dan bukti-bukti yang sangat signifikan sehingga penyidik atau penuntut umum dapat mengungkap tindak pidana terkait secara efektif, mengungkap pelaku-pelaku lain yang memiliki peran lebih besar, serta untuk kasus korupsi harus mengembalikan aset yang telah dikorupsinya.

Namun dalam pelaksanaanya masih ditemukan permasalahan dalam pemberian justice collaborator yang perlu diperbaiki lantaran harus dikembalikan kepada penegak hukum yang menangani perkara narapidana. Dalam konsepnya pemberian justice collaborator disertakan pada saat putusan atau inkrah dari hakim sehingga pemasyrakatan hanya menjalankan tugas pembinaanya saja. Karena hal tersebut dapat dimanfaatkan oleh sebagian oknum dengan jual beli justice collaborator di lembaga penegak hukum. Dan juga seakan-akan lembaga pemasyarakatan yang dititikberatkan dalam pemberian JC. Seharusnya pihak penahan atau pengadilan sudah menebitkan JC pada saat narapidana tersebut ditempatkan dilapas sehingga kesannya lembaga pemasyaraktan yang mengemis untuk diberikan justice collaborator.

\section{PENUTUP}

Pelaksanaan remisi terhadap tindak pidana narkotika di Indonesia diatur dalam Perarturan Perundangan No 99 Tahun 2012 yang mengacu pada Undang-Undang Pemasyarakatan pada pasal 14 yang mengenai hak narapidana salah satunya yaitu 
pemberian remisi. Pada narapidana narkotika termasuk dalam tindak pidana kejahatan luar biasa atau extraordinary crime, sehingga dalam pemberian remisinya berdasarkan PP No 99 Tahun 2012 yang memiliki syarat dan ketentuan khusus dari kasus lainya.

Namun dalam pelaksanaanya berdasarkan PP No 99 Tahun 2012 masih mengalami kendala atau permaslahan bahwa dalam syarat tersebut harus diberikan Justice Collaborator, tetapi hal tersebut menjadi hambatan dan permasalahan yaitu tersebut dapat dimanfaatkan oleh sebagian oknum dengan jual beli justice collaborator di lembaga penegak hukum. Seharusnya pada pemberian JC tersebut dilakukan oleh penegak hukum pengadilan sebelum incrach sudah di lampirkan JC atau tidak sehingga pemasyarakatan tidak dibebankan dengan hal tersebut karena dalam tugas dan fungsinya pemasyarakatan untuk pembinaan.

\section{DAFTAR PUSTAKA}

\section{Buku}

Asshiddiqie, Jimly, 2006, Hukum Acara Pengujian Undang-Undang, Konstitusi Pres:Jakarta.

Siswanto Sunarso,2012, Politik Hukum Dalam Undang-Undang Narkotika.Jakarta:Rineka Cipta

Fuady, Munir, 2007,Dinamika Teori Hukum. Ghalia Indonesia: Bogor.

Kelsen, Hans, 2007, Teori Umum Hukum Dan Negara Bee,Media Indonesia: Jakarta

\section{Perarturan-Perundangan}

Undang-Undang Nomor 12 Tahun 1995 tentang Pemasyarakatan, Lembaran Negara Republik Indonesia Tahun 1995 Nomor 77, Tambahan Lembaran Negara Republik Indonesia Nomor 3614.

Undang-Undang Nomor 39 Tahun 1999 Tentang Hak Asasi Manusia, Lembaran Negara Republik Indonesia Tahun 1999 Nomor 165, Tambahan Lembara Negara Republik Indonesia Nomor 3886.

Peraturan Pemerintah Nomor 99 Tahun 2012 Tentang Perubahan Kedua Atas Peraturan Pemerintah Nomor 32 Tahun 1999 Tentang Syarat dan Tata Cara Pelaksanaan Hak

Warga Binaan Pemasyarakatan, Lembaran Negara Republik Indonesia Tahun 2012 Nomor 225, Tambahan Lembaran Negara Republik Indonesia Nomor 5359.

Indonesia. Kitab Undang-Undang Hukum Pidana.

Indonesia. Undang-Undang No. 8 Tahun 1981 tentang Hukum Acara Pidana (KUHAP).

Indonesia. Undang-Undang No. 35 Tahun 2009 tentang Narkotika.

\section{Website}

Hukum Online. 2020. Syarat Pemberian Remisi Untuk Narapidana Narkotika.(Online)(https://www.hukumonline.com/klinik/detail/ulasan/lt5d0a 55c58343b/syarat-pemberian-remisi-untuk-narapidana-narkotika/ diakses pada Tanggal 10 Mei 2020) 
